\title{
SERVICEABILITY VERIFICATION OF PEDESTRIAN BRIDGES UNDER PEDESTRIAN LOADING
}

\author{
Ivana Štimac Grandić
}

Subject review

Due to their slenderness, pedestrian bridges may vibrate significantly under pedestrian traffic. Many researches in the past few decades deal with the problem of predicting the vibration response induced by human activity reliably. Most of the codes in the field of footbridge design define certain pedestrian comfort criteria which have to be satisfied to fulfil the serviceability in relation to vibration. The main disadvantage of the current European codes (Eurocodes) is lack of defined dynamic models of pedestrian loads for the serviceability state verification in relation with vibration. In this paper a design procedure (with load models recommendation) for verification of the serviceability limit state related to vibration due to pedestrians is proposed. According to the proposed procedure the serviceability verification on a model of a reinforced concrete pedestrian bridge in the Maksimir Park in Zagreb is conducted.

Keywords: pedestrian bridge; pedestrian load models; serviceability verification

Dokaz graničnog stanja uporabljivosti pješačkih mostova pod pješačkim opterećenjem

Pregledni članak

Pješački promet može izazvati značajne vibracije vitkih pješačkih mostova. U proteklih nekoliko desetljeća mnogi se znanstvenici bave problemom pouzdanog predviđanja dinamičkog odgovora (vibriranja) mostova izazvanog ljudskim kretanjem. Većina normi za projektiranje mostova definira određene kriterije koje je potrebno zadovoljiti da bi bilo dokazano granično stanje uporabljivosti vezano uz vibriranje. Osnovni nedostatak važećih europskih normi (Eurokodova) je nedostatak definiranih modela pješačkih opterećenja za koja se provodi dokaz graničnog stanja uporabljivosti vezanog uz vibriranje. U radu je predložen postupak proračuna pješačkih mostova (s preporučenim modelima pješačkog opterećenja) u području graničnog stanja vibracija uzrokovanih pješačkim opterećenjem. Koristeći predloženi postupak proveden je dokaz graničnog stanja uporabljivosti na modelu armiranobetonskog pješačkog mosta u parku Maksimir u Zagrebu.

Ključne riječi: dokaz graničnog stanja uporabljivosti; modeli pješačkih opterećenja; pješački most

\section{Introduction}

Pedestrian bridges are often very slender and flexible structures. Natural frequencies of such structures are often in the range that corresponds to frequency of dynamic excitation caused by walking or running [1]. Thus, such bridges can easily be stimulated to vibrate when pedestrians walk or run across them. Since the main purpose of pedestrian bridges is crossing of pedestrians over the bridge it is important to ensure safety and comfort for the users. Although, there have been cases of destruction of bridges (e.g. in 1154 a wooden bridge collapsed under the crowd in England [2], in 1831 a bridge collapsed while 60 soldiers were marching across it in Broughton [2], a pedestrian bridge in Canton, China collapsed in 1994 [3]) yet this problem is not a regular occurrence. Problems of vibration caused by humaninduced dynamic loading are more often related to the serviceability than the problem of structural safety [4]. Human body can sense very small amplitudes of vibration $(0,001 \mathrm{~mm})$ so the serviceability problem occurs at the level of vibration which is far below the level that causes damage in a structure [2,5]. Many famous pedestrian bridges in the world (such as Millennium Bridge in London [2, 6, 7] Passerelle Solferino in France [6, 8], Toda Park Bridge in Japan [7]) have problems with dynamic behaviour due to vibration caused by walking or running.

Therefore, the problem of vibration on footbridges has been an important topic of scientific research for many years. Also, the various recommendations for the verification of serviceability limit state related to vibration and user's comfort are built into bridge design codes $[2,3]$.

In order to verify serviceability limit state related to vibration due to pedestrians it is necessary to define dynamic pedestrian load. Numerous studies deal with determination of human walking, running or jumping force over the years [2, 8]. While moving across the bridge a pedestrian produces dynamic time varying force, which can be represented by three components: vertical, horizontal longitudinal and horizontal lateral component. Most researches deal with determination of the vertical component because its magnitude is much higher than other two components [2]. Moreover, the most investigated are dynamic forces caused by walking, although pedestrian bridges can be exposed to running, jumping or vandalism loads $[2,8]$.

Until the opening of the Millennium Bridge, there were no significant problems related to horizontal vibrations on pedestrian bridges, so almost all documented problems with pedestrian-induced vibrations were associated with vertical forces and vibrations $[2,9]$. The effects of horizontal vibration on pedestrian bridges have been in the focus for only the last decade [9].

In this paper, the different models of dynamic loads caused by pedestrian crossing the bridge, which can be used in serviceability verification, are presented. Also, a review of criterion and recommendation related to verification of vibration serviceability and assurance of human comfort is presented.

Based on the collected and analyzed data a design procedure for verification of the serviceability limit state related to vibration due to pedestrians is proposed. According to the proposed procedure the serviceability 
verification of a reinforced concrete pedestrian bridge in the Maksimir Park in Zagreb is conducted.

\section{Pedestrian loads}

Pedestrian loads may be a result of walking, running or jumping. Each of these types of human movements can be represented by a force pattern in time. Fig. 1 shows the typical pattern of vertical walking and running force.

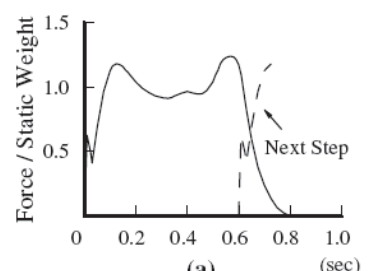

(a)

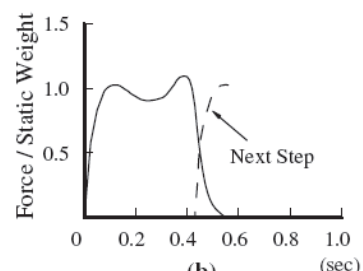

(b)

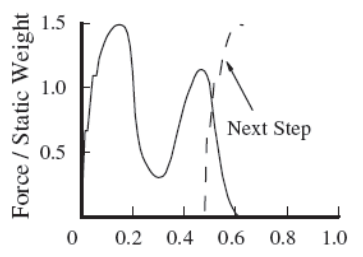

(c)

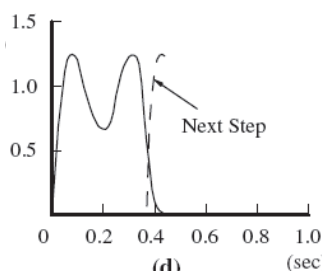

(d)
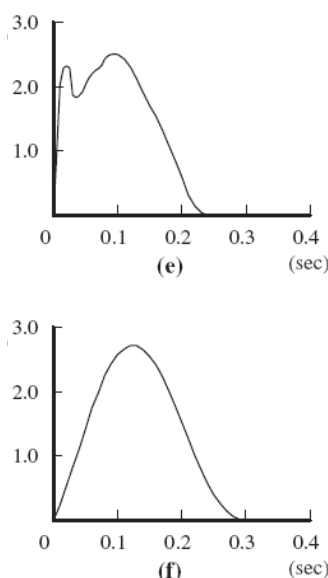

Figure 1 Typical vertical patterns for: (a) slow walk, (b) normal walk, (c) brisk walk, (d) fast walk, (e) slow jog, (f) running [2]

Any type of human movement is characterized by the usual step frequency range. The usual frequency range of human walking, running and jumping is shown in Tab. 1 [10]. Typically, the frequency of human walking falls in the range between 1,6 and 2,4 Hz. The mean value is $2 \mathrm{~Hz}$ with the standard deviation of 0,175 . This means that 50 $\%$ of pedestrians walk at rates between 1,95 and $2,1 \mathrm{~Hz}$ or $95 \%$ of pedestrians walk at rates between 1,65 and 2,35 $\mathrm{Hz}[2,11,5]$. Commonly adopted mean value frequency for running and jumping is $2,5 \mathrm{~Hz}$ [10].

Table 1 Step frequencies (Hz)

\begin{tabular}{|c|c|c|c|}
\hline & Slow & Normal & Fast \\
\hline Walking & $1,4-1,7$ & $1,7-2,2$ & $2,2-2,4$ \\
\hline Running & $1,9-2,2$ & $2,2-2,7$ & $2,7-3,3$ \\
\hline Jumping & $1,3-1,9$ & $1,9-3,0$ & $3,0-3,4$ \\
\hline
\end{tabular}

Despite sharing the same step frequency, individuals' steps length $l_{\mathrm{s}}$ can vary due to different body heights and leg length.

Leg length determines step length and hence the speed of an individual. Fig. 2 shows the relationship between step length, speed and step frequency for walking and running.

In the case of very slow walking with a step frequency of less than $1 \mathrm{~Hz}$ (long period of ground contact, dynamic load is equal to the static load (body weight). For fast walking with frequency between 2 and $2,5 \mathrm{~Hz}$ dynamic load increases up to 1,5 in comparison to the static load. For very fast running $(>3,5 \mathrm{~Hz})$ maximum (peak) dynamic load is about three times greater than the static loads caused by the weight of a pedestrian. The relationship between the step frequency, contact period and ratio of peak dynamic and static load is shown in Fig. 3.

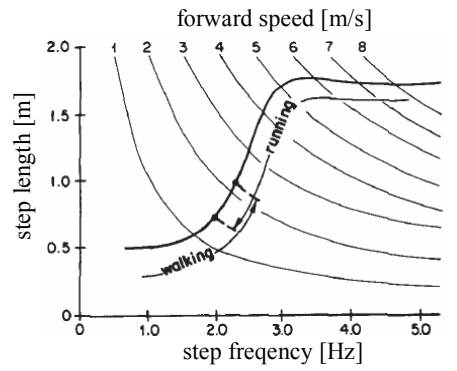

Figure 2 Relation between step length, speed and step frequency [3]

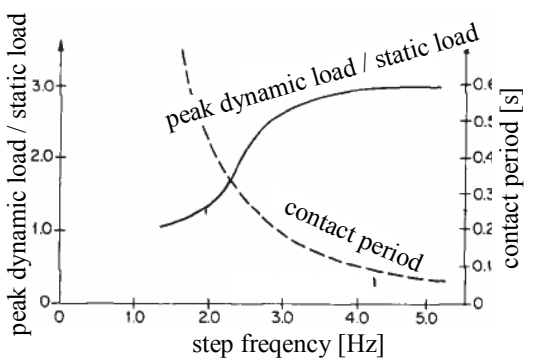

Figure 3 The relationship between the step frequency, contact period and ratio of peak dynamic and static load [3]

\subsection{Walking force models}

Rhythmical human body motion during at least 20 seconds leads to almost periodic dynamic forces $[5,11]$. Therefore a force caused by walking can be represented by time varying periodic function. The force amplitude mainly depends on the type of walking (slow, normal, fast), step frequency and body weight. During walking one foot is always in contact with the ground, the loading does not disappear at any time like it is in the case when running. During the period of transferring the body weight from one foot to the other the force functions for each leg overlap (Fig. 4).
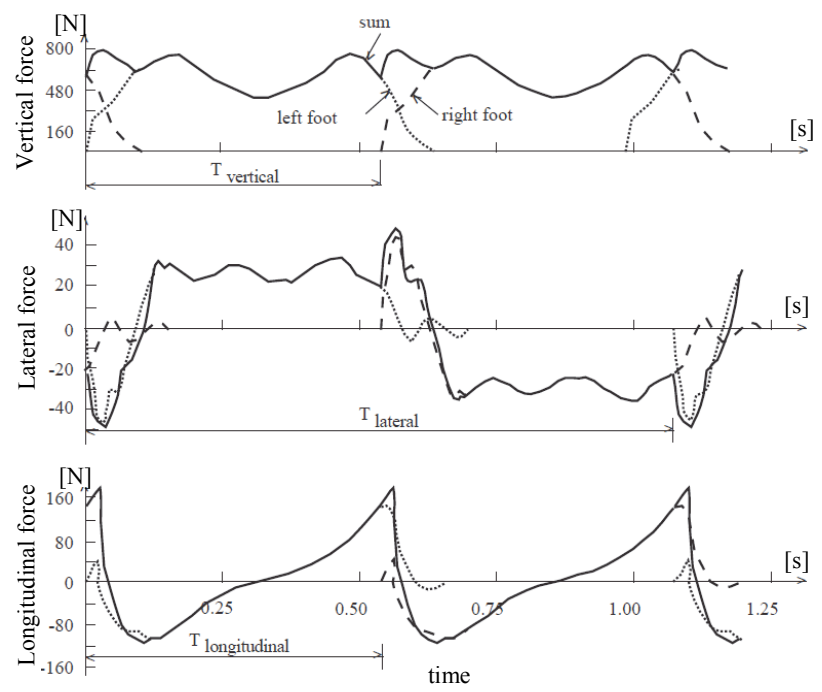

Figure 4 Walking periodic force in vertical, lateral and longitudinal direction [2] 
The vertical force component is greater than the horizontal one, but the lateral and longitudinal horizontal components can also cause vibration related problems of slender bridges, especially if the interaction between pedestrians and the bridge is achieved.

Frequency of lateral movement, which occurs as a result of moving the centre of mass from one foot to the other, is equal to half of the step frequency, i.e. half the frequency of vertical and longitudinal movement $[2,4]$.

General shapes for continuous forces in vertical and horizontal directions have been constructed assuming a perfect periodicity of the force (both human feet produce exactly the same force and all the steps are identical) as it can be seen in Fig. 4.

Hence, the periodic components of walking force can be represented by Fourier series [4]:

$$
\begin{aligned}
& F_{p, v}(t)=G+G \sum_{i=1}^{n} \alpha_{i, v} \sin \left(2 \cdot \pi \cdot i \cdot f_{s} \cdot t-\varphi_{i}\right), \\
& F_{p, \text { lat }}(t)=G \sum_{i=1}^{n} \alpha_{i, \text { lat }} \sin \left(2 \cdot \pi \cdot i \cdot \frac{f_{s}}{2} \cdot t-\varphi_{i}\right), \\
& F_{p, \text { long }}(t)=G \sum_{i=1}^{n} \alpha_{i, \text { long }} \sin \left(2 \cdot \pi \cdot i \cdot f_{s} \cdot t-\varphi_{i}\right),
\end{aligned}
$$

where $F_{p, v}(t)$ is a vertical periodic force, $F_{p, \text { lat }}(t)$ is a lateral periodic force, $F_{p, \text { long }}(t)$ is a longitudinal periodic force, $G$ is a static load which corresponds to the pedestrian's weight, $f_{s}$ is a step frequency, $\alpha_{i, v}, \alpha_{i, \text { lat }}$ and $\alpha_{i, \text { long }}$ are the Fourier coefficients of the $i^{\text {th }}$ harmonic for vertical, lateral and longitudinal forces, $n$ is a total number of contributing harmonics, $\varphi_{i}$ is a phase shift of the $i^{\text {th }}$ harmonic.

\begin{tabular}{|c|c|c|c|}
\hline Author(s) & $\begin{array}{c}\text { Fourier coefficients / Phase } \\
\text { angles }\end{array}$ & Comment & $\begin{array}{c}\text { Load } \\
\text { direction }\end{array}$ \\
\hline $\begin{array}{l}\text { Blanchard } \\
\text { et al. }\end{array}$ & $\alpha_{1}=0,257$ & up to $4 \mathrm{~Hz}$ & vertical \\
\hline \multirow{3}{*}{$\begin{array}{l}\text { Bachmann } \\
\text { et al. }\end{array}$} & $\begin{array}{l}\alpha_{1}=0,4 / 0,5 \\
\alpha_{2}=\alpha_{3}=0,1 \\
\varphi_{2}=\varphi_{3}=\pi / 2\end{array}$ & at $2 / 2,4 \mathrm{~Hz}$ & vertical \\
\hline & $\begin{array}{l}\alpha_{1}=\alpha_{2}=\alpha_{3}=0,1 \\
\varphi_{2}=\varphi_{3}=\pi / 2\end{array}$ & at $2 \mathrm{~Hz}$ & lateral \\
\hline & $\alpha_{1 / 2}=0,1 ; \alpha_{1}=0,2 ; \alpha_{2}=0,1$ & at $2 \mathrm{~Hz}$ & longitudinal \\
\hline \multirow{3}{*}{$\begin{array}{l}\text { Charles \& } \\
\text { Hoorpah }\end{array}$} & $\alpha_{1}=0,4$ & - & vertical \\
\hline & $\alpha_{1}=0,05$ & - & lateral \\
\hline & $\alpha_{1}=0,2$ & - & longitudinal \\
\hline Young & $\begin{array}{l}\alpha_{1}=0,37\left(f_{s}-0,95\right) \leq 0,5 \\
\alpha_{2}=0,054+0,0088 f_{s} \\
\alpha_{3}=0,026+0,015 f_{s} \\
\alpha_{4}=0,01+0,0204 f_{s}\end{array}$ & $\begin{array}{c}\text { mean } \\
\text { values of } \\
\text { DLF for } f_{s} \\
=1 \div 2,8 \mathrm{~Hz}\end{array}$ & vertical \\
\hline \multirow{3}{*}{ Schulze } & $\begin{array}{l}\alpha_{1}=0,37 ; \alpha_{2}=0,1 ; \alpha_{3}=0,12 ; \\
\alpha_{4}=0,04 ; \alpha_{5}=0,08\end{array}$ & at $2 \mathrm{~Hz}$ & vertical \\
\hline & $\begin{array}{l}\alpha_{1}=0,039 ; \alpha_{2}=0,01 \\
\alpha_{3}=0,043 ; \alpha_{4}=0,012 \\
\alpha_{5}=0,015\end{array}$ & at $2 \mathrm{~Hz}$ & lateral \\
\hline & $\begin{array}{l}\alpha_{1 / 2}=0,037 ; \alpha_{1}=0,204 ; \\
\alpha_{3 / 2}=0,026 ; \alpha_{2}=0,083 ; \\
\alpha_{5 / 2}=0,024\end{array}$ & at $2 \mathrm{~Hz}$ & longitudinal \\
\hline
\end{tabular}

The pedestrian's weight is usually determined as 700 $\mathrm{N}[1,2,12,13]$ or $800 \mathrm{~N}[2,3,14]$.

Various Fourier coefficients, i.e. dynamic load factors (DLF), are suggested in the literature [2,3]. The dynamic load factors are defined as the ratio of the force amplitude for each harmonic to the pedestrian's weight. Some of them are listed in Tab. 2. Number of contributing harmonics, depending on the author, varies from 1 to 5 (Tab. 2).

The phase shifts exhibit in reality a large scatter because of the many parameters they depend on [15]. As it can be seen in Tab. 2, only Bachman proposed the phase shifts as $\varphi_{2}=\varphi_{3}=\pi / 2$.

The periodic forces defined according Eqs. (1 to 3 ) are not stationary. It moves along the bridge with certain speed. In references $[2,3,10]$ the force speed is defined as $v=0,9 \cdot f_{\mathrm{s}}$ where 0,9 is the step length in meters. Besides the individual pedestrians, the bridge can be loaded with a group of pedestrians or continuous pedestrian stream. Influence of group of pedestrians on bridge is generally taken into account by the factors of synchronization of step frequencies [3].

\subsection{Load models in codes}

The first design code which dealt with the footbridge vibration serviceability issue was BS 54000:Part2 [16]. The procedure for checking vertical vibrations due to a single pedestrian walking with step frequency $f_{s}$ equal to the fundamental natural frequency $f_{v}$ of the bridge in vertical direction was defined. The single pedestrian load model is defined as a moving sinusoidal force:

$$
F_{p, v}(t)=180 \cdot \sin \left(2 \cdot \pi \cdot f_{v} \cdot t\right), \mathrm{N}
$$

where only a pulsating part of the walking force defined in Eq. (1) is taken into account. $G=700 \mathrm{~N}$ and DLF is 0,275 (taken according to Blanchard). The force speed is $v=0,9 \cdot f_{s}$. Many years later an updated version [17] requires the lateral vibration checking but procedure for the dynamic analysis is not given. Also, the procedure for vertical vibration analysis is the same as in the code version from 1978 [16] despite the fact that many drawbacks have been identified. The same procedure for checking vertical vibrations as in BS is established in The Ontario Highway Bridge Design Code, Canadian Highway Bridge Design Code and The Hong Kong Structures Design Manual for Highways and Railways [2].

In paper [2] the authors reported that the American Guide Specification gives the target value for the minimum natural frequencies of bridge based on the pulsating force with DLF of 0,5 for the first harmonic.

In the European prenorm ENV 1992-2:1996 [18] for the design of concrete bridges there is written that maximal vertical acceleration should be calculated using pulsating force defined as in Eq. (4) moving with a constant speed of $0,9 \cdot f_{v}$, while the prenorm ENV 19952:1997 [19] for the design of timber bridge structures defined the moving force as

$F_{p, v}(t)=280 \cdot \sin \left(2 \cdot \pi \cdot f_{v} \cdot t\right), \mathrm{N}$

The amplitude of $280 \mathrm{~N}$ corresponds to the DLF of 0,4 for the first harmonic and average pedestrian weight of $700 \mathrm{~N}$. The prenorm [19] also defines a horizontal lateral moving force model as 


$$
F_{p, h}(t)=70 \cdot \sin \left(2 \cdot \pi \cdot f_{h} \cdot t\right), \mathrm{N}
$$

where $f_{h}$ is the fundamental natural frequency in the lateral direction and DLF of 0,1 is taken for the first harmonic. The force speed is defined as $0,9 \cdot f_{s}=0,9 \cdot f_{v}=$ $0,9 \cdot f_{h} \cdot 2[19]$.

In Sestra guidelines [13], there is written that in the Annex to Eurocode 1, covering dynamic models of pedestrian loads, the recommended vertical load was defined in the same way as in the prenorm ENV 19952:1997 [19]. In Setra guidelines it is reported that this model has been deleted from the Eurocode [13].

The current European norm for determination of traffic loads on bridges [20] does not recommend the load models for serviceability limit verification due to pedestrians. It says only that the appropriate dynamic models of pedestrian loads should be defined (the dynamic models of pedestrian loads may be given in the National Annex). Unfortunately, the load models in the Croatian National Annex [21] are not defined. Due to the fact that the basic standard [20] does not define the pedestrian load models the Guidelines for the design of footbridges [3] gives the certain pedestrian load models. The load models are divided into three categories: Single Pedestrian Load Model (DLM1), Load Model for Group of Pedestrians (DLM2) and Load Model for a Continuous Pedestrian Steam (DLM3) as it can be seen in Fig. 5. Instead of pulsating forces in vertical and lateral direction which move with the speed of $0,9 \cdot f_{s}$, the stationary pulsating forces applied at the most adverse position on the bridge (which substitute the influence of moving forces) are defined. Vertical and lateral component should be considered separately.

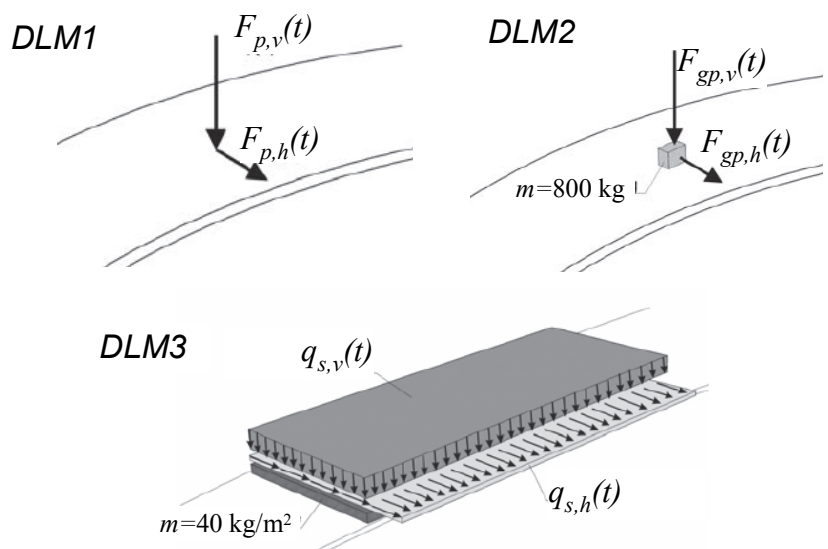

Figure 5 DLM1, DLM2 and DLM3 according to [3]

DLM1 defines vertical $F_{p, v}$ and horizontal (lateral) component $F_{p, h}$ as

$$
\begin{aligned}
& F_{p, v}(t)=180 \cdot \sin \left(2 \cdot \pi \cdot f_{v} \cdot t\right), \mathrm{N} \\
& F_{p, h}(t)=70 \cdot \sin \left(2 \cdot \pi \cdot f_{h} \cdot t\right), \mathrm{N}
\end{aligned}
$$

The DLF is 0,4 for vertical and 0,1 for horizontal direction and the pedestrian's weight is $700 \mathrm{~N}$. The reduction factor $R=180 /(0,4 \cdot 700)$ is built in determination of amplitude of vertical stationary pulsating component. The reduction factor provides similar dynamic response of the structure due to pulsating stationary force placed at most adverse position in comparison to dynamic response due to moving pulsating force determined without the reduction factor. For example, Allen And Murray give $R=0,7$ while Grundman takes $R=0,6$ [2]. Amplitude of horizontal component in DLM1 is defined as DLF times pedestrian weigh $(0,1 \cdot 700=70)$ without the reduction factor, what is not consistent.

The vertical component of DLM1 was also contained in German guidelines for the bridge design DINFachbericht 102 form 1995 [3].

DLM2 describes the effect of $8 \div 15$ persons walking across the bridges (Eqs. $(9,10))$. The factor of synchronisation of step frequencies and the phase shift between pedestrians is taken into account by coefficients $k_{v}\left(f_{v}\right)$ and $k_{h}\left(f_{h}\right)$ (Fig. 6).

$$
\begin{aligned}
& F_{g p, v}(t)=180 \cdot k_{v}\left(f_{v}\right) \cdot \sin \left(2 \cdot \pi \cdot f_{v} \cdot t\right), \mathrm{N} \\
& F_{g p, h}(t)=70 \cdot k_{h}\left(f_{h}\right) \cdot \sin \left(2 \cdot \pi \cdot f_{h} \cdot t\right), \mathrm{N}
\end{aligned}
$$

$F_{p, v}$ and $F_{p, h}$ should be associated with a static mass of $800 \mathrm{~kg}$ (if unfavourable) in calculation of natural frequencies and accelerations. Added mass represents weight of group of pedestrians.
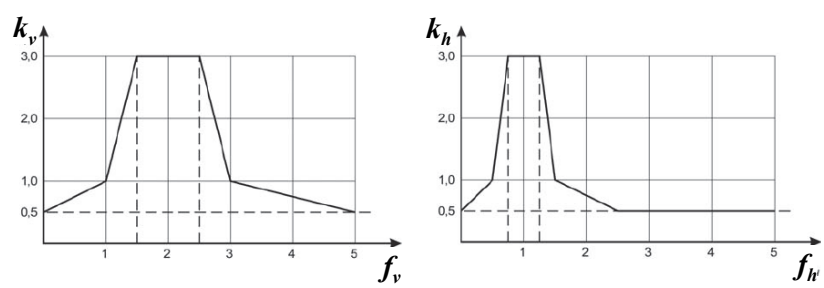

Figure 6 Coefficients $k_{v}\left(f_{v}\right)$ and $k_{h}\left(f_{h}\right)_{[3]}$

The continuous pedestrian stream (DLM3) is modelled as a uniformly distributed pulsating load with a vertical and a lateral component (Eq. $(11,12))$.

$$
\begin{aligned}
& q_{s, v}(t)=12,6 \cdot k_{v}\left(f_{v}\right) \cdot \sin \left(2 \cdot \pi \cdot f_{v} \cdot t\right), \mathrm{N} / \mathrm{m}^{2} \\
& q_{s, h}(t)=3,2 \cdot k_{h}\left(f_{h}\right) \cdot \sin \left(2 \cdot \pi \cdot f_{h} \cdot t\right), \mathrm{N} / \mathrm{m}^{2}
\end{aligned}
$$

The load should be applied in the way to produce the most unfavourable loading case (depending on the mode shape the total span or a part of the span should be loaded). Model is based on the assumption of acceptable pedestrian density of 0,6 person $/ \mathrm{m}^{2}$. The static mass of $400 \mathrm{kN} / \mathrm{m}^{2}$ (if unfavourable) should be applied at same location. The reduction factor for uniformly distributed load of 0,75 is incorporated in Eqs. (11 and 12) [3].

The similar recommendations can be found in the Guide to basis of bridge design [22]. The main difference between load models defined in the Guidelines for the design of footbridges [3] and those defined in the Guide to basis of bridge design [22] is lack of the reduction coefficient $R$ in the last [22]. Also, in reference [22] a single pedestrian load model is omitted. DLM2 for vertical component defined in [22] is

$F_{g p, v}(t)=280 \cdot k_{v}\left(f_{v}\right) \cdot \sin \left(2 \cdot \pi \cdot f_{v} \cdot t\right), \mathrm{N}$

while a lateral component is the same as in Eq. (7).

DLM3 in [22] is defined as: 


$$
\begin{aligned}
& q_{s, v}(t)=15 \cdot k_{v}\left(f_{v}\right) \cdot \sin \left(2 \cdot \pi \cdot f_{v} \cdot t\right), \mathrm{N} / \mathrm{m}^{2} \\
& q_{s, h}(t)=4 \cdot k_{h}\left(f_{h}\right) \cdot \sin \left(2 \cdot \pi \cdot f_{h} \cdot t\right), \mathrm{N} / \mathrm{m}^{2} .
\end{aligned}
$$

In all previously mentioned codes there is no definition of the longitudinal component of the walking force because, in practice, the longitudinal component has, in general, little influence on most bridges [13]. Therefore, in the following chapters, the horizontal lateral component will be called horizontal component.

\section{Vibration comfort criteria requirements for pedestrian bridges}

The human perception of vibration is subjective and depends on many parameters (age, gender, mood, weather, time of the day, etc.) [7]. According to researches [15, 23] women are more sensitive to vibrations than men and the sensitivity decreases with ageing. The perception of the acceptability of vibrations depends on two main criteria: frequency and acceleration. There are a lot of researches dealing with the problem of determining the acceptable criteria but unique criteria were not established for the reasons outlined earlier. Comfort criteria are usually defined by frequency range that should be avoided in the design and/or by limitation of acceleration. Structures whose natural frequencies fall outside certain frequency range will generally not be at risk of resonance loading. For structures with frequencies inside the range the dynamic analysis is required. The resulting structural acceleration should be inside certain limit value to ensure pedestrian comfort.

\subsection{Recommended limit values for frequencies}

Various sources define a frequencies range were the problems related to the vibration of construction caused by pedestrian dynamic loading are not expected. For example, Allen and Murray [2, 12] give a simplified method for determination of a minimum vertical fundamental frequency that is acceptable for one span simple supported footbridge is

$$
f_{v} \geq 2,86 \cdot \ln \left(\frac{8}{\zeta \cdot W}\right), \mathrm{Hz}
$$

where $W$ is the bridge total weight in $\mathrm{kN}, \zeta$ is the damping ratio.

Some codes provide simplified rules which have to be satisfied to avoid dynamic problems (e.g. Spanish Bridge design Code limited deflections due to frequent live loads of $2 \mathrm{kN} / \mathrm{m}^{2}$ on $L_{\text {span }} / 100$ [3]).

One of the earliest studies conducted by Blanchard [2] proposed to check serviceability in pedestrian bridges with vertical fundamental natural frequency up to $5 \mathrm{~Hz}$. A lot of codes and standards adopted this recommendation. For example, BS 5400: Part 2 (Appendix C) gives instruction for checking vertical vibration for footbridges having the fundamental vertical natural frequencies up to $5 \mathrm{~Hz}$ [16]; the Hong Kong Structures Design Manual for Highways and Railways requires controlling the acceleration response due to a pedestrian in accordance with BS 5400 [2]; prenorm ENV 1995-2 for wooden bridges [19] requires the calculation of the acceleration response for bridges with vertical natural frequencies lower than $5 \mathrm{~Hz}$; while prenorm ENV 1992-2 for concrete bridges [18] defines that vibration limit state is satisfied if the fundamental frequency of vertical vibration is above $5 \mathrm{~Hz}$ and gives the recommendation to avoid first vertical natural frequency between 1,6 and 2,4 for the first walking harmonics and between 2,5 to 4,5 for the second or higher walking harmonics. Swiss standard SIA 260 [24] and Codes issued by Comite' Euro-International $\mathrm{du}$ Be'ton $[25,26]$ requires avoiding footbridge vertical natural frequencies in the range of the first $(1,6 \div 2,4 \mathrm{~Hz})$ and the second walking harmonics $(3,5 \div 4,5 \mathrm{~Hz})$ for pedestrians and cyclists, with the addition of frequencies $2,4 \div 3,5 \mathrm{~Hz}$ if joggers/runners can appear on the structure. If these requirements are not fulfilled then the vibration response of the structure should be checked. EN 1990 in Appendix 2 [27] obliges the designers to verify the acceleration if the fundamental frequency of the deck is less than $5 \mathrm{~Hz}$ for vertical vibration. The American Guide Specification for FRP pedestrian bridges [28] defines that fundamental natural frequency in vertical direction shall be greater than $5 \mathrm{~Hz}$ to avoid any issues associated with the first and second walking harmonic while [29] suggest avoiding frequencies below $3 \mathrm{~Hz}$ for the first walking harmonic.

Similar recommendations also exist for horizontal vibration in lateral direction: Eurocode 5 for wooden bridges [19] and EN1990 in Appendix 2 [27] requires the calculation of the acceleration response for bridges with natural frequencies lower than $2,5 \mathrm{~Hz}$ for horizontal (lateral) modes; an updated version of BS 5400: BD 37/01 [17] requires checking the vibration serviceability in the lateral direction for all footbridges with fundamental lateral frequencies lower than 1,5 Hz; while SIA 260 [24] gives the limit at 1,3 Hz. Bachnman and Amman suggest avoiding lateral frequencies between $0,8 \div 1,2 \mathrm{~Hz}$ for the first and possibly $1,6 \div 2,4 \mathrm{~Hz}$ for the second walking harmonic [2]. The American Guide Specification [28] defines that fundamental natural frequency in horizontal direction shall be greater than $3 \mathrm{~Hz}$ to avoid any issues due to side to side motion while [29] gives the limit at 1,3 $\mathrm{Hz}$ for first walking harmonic.

Although some codes recommend avoiding bridge fundamental natural frequency in the range of second walking harmonics, according to [30] lateral vibrations are not effected by the second walking harmonic while vertical vibration problems caused by second walking harmonic, so far, are not reported in the literature [30].

\subsection{Recommended limit values for acceleration}

As a serviceability criterion Blanchard [2] proposed that the acceleration response due to one pedestrian should not exceed the limit of $0,5 f_{v}^{1 / 2} \mathrm{~m} / \mathrm{s}^{2}$ in vertical direction. This recommendation is adopted in BS 5400 [16] as well as in British standard for accessing vibration serviceability of bridges BD 37/01 [17], the Hong Kong Structures Design Manual for Highways and Railways [2] and prenorm ENV 1992-2 for concrete bridges [18]. The Ontario Highway Bridge Design Code adopted limit value of vertical acceleration as $0,25 f_{v}^{0,78} \mathrm{~m} / \mathrm{s}^{2}[1]$ as well as the 
Danish Road Directorate [7]. Bachmann et al. [5] proposed a constant acceleration acceptance level of 0,5 $\mathrm{m} / \mathrm{s}^{2}$. A constant level of acceleration is also suggested in Japanese Footbridge Design Code [7] and current Eurocodes [19, 27] (Tab. 3). All previous values are determined to limit vertical acceleration. Only a few codes define maximum acceptable acceleration in horizontal (lateral) direction as it can be seen from Tab. 3 .

Table 3 Limit values for acceleration $\left(\mathrm{m} / \mathrm{s}^{2}\right)$

\begin{tabular}{|l|l|l|}
\hline \multicolumn{1}{|c|}{ Direction } & Vertical & Horizontal \\
\hline EN 1990 & 0,7 & $\begin{array}{l}0,2^{*} \\
0,4 * *\end{array}$ \\
\hline ENV 1995-2 & 0,7 & 0,2 \\
\hline $\begin{array}{l}\text { ENV 1992-2 } \\
\text { BS 5400: BD 37/01 }\end{array}$ & $0,5 f_{v}^{1 / 2}$ & - \\
\hline Hong Kong Structures Design & $0,5 f_{v}^{1 / 2}$ & 0,15 \\
\hline Ontario Bridge Code ONT 83 & $0,25 f_{v}^{0,78}$ & - \\
\hline Japanese Footbridge Design Code & 1,0 & - \\
\hline & $*$ normal use \\
& $* *$ crowd conditions \\
\hline
\end{tabular}

\section{Proposed design procedure}

In general, it is important that the design procedure satisfies two somewhat contradictory requirements: to be simple and as accurate as possible.

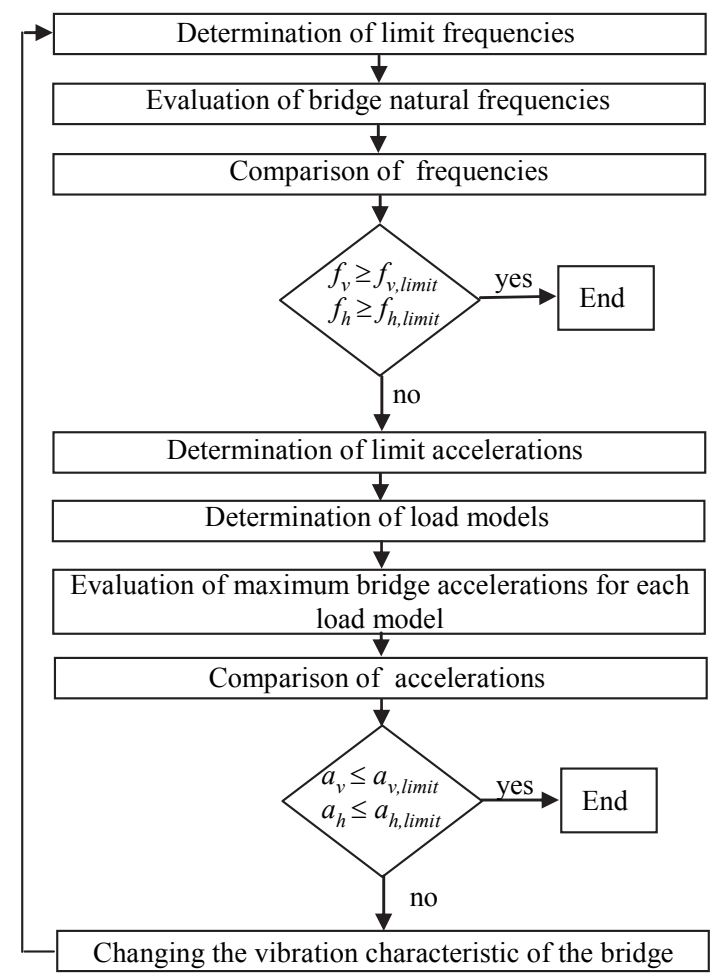

Figure 7 The flow-chart for the proposed design procedure

The proposed design procedure should contain the following steps:

- determination of fundamental frequency limit values in horizontal and vertical directions $\left(f_{v, \text { limit }}, f_{h \text {,limit }}\right)$ above which the vibration limit state is satisfied,

- evaluation of bridge natural frequencies in vertical and horizontal direction $\left(f_{v}, f_{h}\right)$

- comparison of bridge natural frequencies to the limit values.
If the frequencies are higher than the limit values the serviceability limit state in relation to vibration is satisfied, otherwise the verification procedure will be continued according to the following steps:

- determination of the acceleration limit values $\left(a_{v, \text { limit }}\right.$, $\left.a_{h \text { limit }}\right)$ to ensure pedestrian comfort,

- determination of pedestrian loads (determination of load models),

- evaluation of maximum accelerations $\left(a_{v}, a_{h}\right)$ of bridge for each load model,

- comparison of bridge maximum accelerations and limit accelerations.

The proposed design procedure is shown in the flowchart in Fig. 7.

\subsection{Proposed limit values}

The limit value for vertical fundamental frequency $f_{v, \text { limit }}$ is $5 \mathrm{~Hz}$ (accepted limit suggested in current EN 1990 [27] and in most of the codes mentioned in Chapter 3.1). The limit value for horizontal fundamental frequency is adopted according to [27] as $f_{h \text {,limit }}=2,5 \mathrm{~Hz}$.

The limit values for acceleration in vertical and horizontal directions are $a_{v, \text { limit }}=0,7 \mathrm{~m} / \mathrm{s}^{2}$ and $a_{h \text {,limit }}=0,2$ $\mathrm{m} / \mathrm{s}^{2}$, respectively (according to [27]).

\subsection{Natural frequencies evaluation}

In the evaluation of natural frequencies the mass of any permanent load should be taken into account $[22,18]$. The mass of pedestrians should be taken into account when the modal mass of the pedestrians is more than $5 \%$ of the deck modal mass according to $[4,30]$. In some load models $[3,22]$ the additional pedestrian mass which has to be taken into account (if unfavourable) is defined. The flexural stiffness of the deck should be determined using short term dynamic elastic properties of structural materials (i.e. dynamic modulus of elasticity and uncracked cross section for concrete bridges [18]) and, if significant, of the fences and parapets [18, 22]. For example, the dynamic modulus of elasticity $E_{\mathrm{din}}$ for concrete is defined as $5 \div 10 \%$ greater value than static modulus of elasticity $E[15,31]$.

There are several ways to calculate the natural frequency of the bridge (especially for preliminary check). It can be generally divided in two groups: (i) by the finite element method, (ii) using hand formulas (closed-form solutions). A closed form solution for calculation of frequencies of simple structural systems (i.e. single-span and continuous beams, circular and rectangular plates) can be found in reference $[15,32]$.

The simplified method for determination of frequencies of single-span beams [32] is represented by Eq. (17):

$f_{i}=\frac{\alpha_{i}}{2 \pi} \sqrt{\frac{E \cdot I}{m l^{4}}}, \mathrm{~Hz}$

where $f_{i}$ is the $i^{\text {th }}$ natural frequency, $I$ is the moment of inertia, $\alpha_{i}$ is the coefficient of the $i^{\text {th }}$ mode of single-span 
beams with various support condition, $m$ is the mass of the structure per meter, $l$ is the span length.

\subsection{Proposed load models}

The load models suggested by the author of this paper are based on stationary pulsating force instead of moving pulsating force proposed in some codes [13, 14, 15, 16]. There are two main reasons for adopting the stationary force instead of the moving one: (i) simplicity of acceleration assessment, (ii) lack of easily available software able to conduct dynamic analysis due to moving loads. The validity of proposed load model based on stationary pulsating force instead of moving pulsating force will be shown in Chapter 5 .

The three different load models DLM1, DLM2 and DLM3, similar as in FIB Bulletin 32 [3], are accepted (Fig. 5). The additional mass in DLM2 and DLM3 is defined in Fig. 5. The vertical components of DLM1 and DLM2 and both components of DLM3 are adopted as in Eqs. (7), (9), (11) and (12). The horizontal components are different from those defined in Chapter 2.2 because of lack of reduction factor $R$ in Eqs. (8 and 10). Proposed horizontal forces for DLM1 and DLM2 are:

$$
\begin{aligned}
& F_{p, h}(t)=45 \cdot \sin \left(2 \cdot \pi \cdot f_{h} \cdot t\right), \mathrm{N} \\
& F_{g p, h}(t)=45 \cdot k_{h}\left(f_{h}\right) \cdot \sin \left(2 \cdot \pi \cdot f_{h} \cdot t\right), \mathrm{N}
\end{aligned}
$$

where $k_{h}\left(f_{h}\right)$ is the coefficient defined in Fig. $6, R$ is taken as 0,64 what is similar to the reduction factor defined for vertical force.

The designer, in consultation with the owner/investor, selects the load model(s) for verification of vibration for each bridge based on the expected pedestrian traffic.

\subsection{Evaluation of accelerations}

Evaluation of accelerations takes into account the damping of the footbridge by using the damping ratio $\zeta$ or the logarithmic decrement $\delta$, which is equal to $2 \pi \zeta$.

Each structure possesses some capability to dissipate energy that is represented by damping. In general, the amount of damping depends on the level of vibrations and it is very difficult to model mathematically the damping mechanism [2]. Bachman et al. [5] give the damping ratio values for concrete, steel and composite bridges based on measured damping on 43 bridges at the vibration level caused by one pedestrian walking at the bridge fundamental frequency. In [13, 30, 33] the damping ratio for timber bridges is defined. Where no other values have been verified the damping ratio for evaluation of acceleration may be taken as in Tab. 4 .

The maximum acceleration can be determined by the finite element method or by using simplified methods (analytical solutions) for simple structural systems as single span systems and two or three span simply supported continuous systems loaded with one pedestrian. In literature, there are a lot of simplified methods developed to facilitate serviceability verification. Some of analytical solutions can be found in references [2, 3, 5]. The simplified methods for assessing accelerations of timber bridges constructed with simply supported beams or trusses is given in Annex B of Eurocode for timber bridges [33] but it is not clear which load models were used in determination of these simplified methods.

Table 4 Values of mean damping ratio $\zeta$ for pedestrian bridges

\begin{tabular}{|l|c|c|c|}
\hline \multirow{2}{*}{\multicolumn{1}{|c|}{ Construction type }} & \multicolumn{3}{c|}{$\zeta / \%$} \\
\cline { 2 - 4 } & min. & mean & max. \\
\hline Reinforced concrete & 0,8 & 1,3 & 2,0 \\
\hline Prestressed concrete & 0,5 & 1,0 & 1,7 \\
\hline Composite (concrete-steel) & 0,3 & 0,6 & - \\
\hline Steel & 0,2 & 0,4 & - \\
\hline \multirow{2}{*}{ Timber } & - & $1,0 *$ & - \\
\hline * structures without mechanical joints & $1,5 *$ & - \\
$* *$ structures with mechanical joints \\
\hline
\end{tabular}

In this section only the method for single-span beams according to Grundman [2,3] is shown. This method is based on assumption that single pedestrian is walking across the bridge with frequency equal to fundamental natural bridge frequency.

Maximum acceleration response due to moving pulsating force $F_{p}(t)=F \cdot \sin \left(2 \cdot \pi \cdot f_{s} \cdot t\right)$ by Grundman is given by:

$a=0,6 \cdot \frac{F}{M_{\mathrm{gen}}} \cdot \frac{\pi}{\delta}\left(1-\mathrm{e}^{-n \cdot \delta}\right), \mathrm{m} / \mathrm{s}^{2}$

where $F$ is the amplitude of pulsating force (DLF times $G), M_{\mathrm{gen}}$ is the mass of equivalent SDOF oscillator and $n$ is the number of steps needed to cross the span (number of cycles per span). 0,6 is the reduction factor $R$ due to chancing the excitation point (taking account moving of the excitation force along the bridge). If $R=1$, Eq. (20) can be used for calculating the acceleration due to stationary pulsating force in the middle of the span.

Acceleration due to group of pedestrians can be estimated as the acceleration due to single pedestrian multiplied by the factor of synchronization [3]. For DLM2 factors of synchronization can be taken from Fig. 6.

For more complex structures, or more complex load models it is necessary to use finite element model(s) to calculate the maximum acceleration.

\section{Example}

Verification of the serviceability limit state related to vibration due to pedestrians according to the proposed procedure in Chapter 4 is conducted on a model of reinforced concrete pedestrian bridge which is in designing process and will be built in the Maksimir Park in Zagreb. The bridge model is based on the data taken from the conceptual design documentation [34]. The validity of proposed load models based on stationary pulsating force instead of moving pulsating force will be shown.

The bridge is designed as one span structure fixed at both ends in massive abutments (Fig. 8(a)). Cross section of the spanning structure is shown in Fig. 8(b). The additional deck surfacing over the main concrete structure is not provided. At both sides of the spanning structure the steel railings with vertical filling rods are designed. 
The estimated mass of each railing is $0,4 \mathrm{kN} / \mathrm{m}$. Modulus of elasticity of concrete is $E=3,2 \times 10^{10} \mathrm{~N} / \mathrm{m}^{2}$.

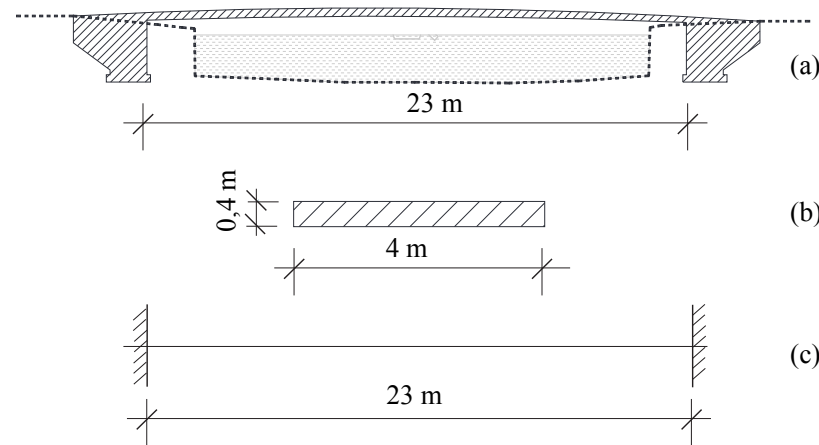

Figure 8 (a) the bridge longitudinal section (b) the bridge cross section; (c) the bridge model

For determination of fundamental natural frequencies in vertical and horizontal direction the simplified method presented by Eq. (17) is used.

According to Eq. (17) and taking into account $I_{y}=0,213 \mathrm{~m}^{4}, I_{z}=2,13 \mathrm{~m}^{4}, l=23 \mathrm{~m}, \alpha_{1}=4,73, E_{\mathrm{din}}=1,05 \cdot E$, $m=4160 \mathrm{~kg} / \mathrm{m}$, where $m$ is the mass of the permanent load, the fundamental natural frequencies in vertical and horizontal direction are calculated as $f_{v}=2,79 \mathrm{~Hz}$ and $f_{h}=27,9 \mathrm{~Hz}$

In horizontal direction the vibration limit state is satisfied due to the fact that bridge frequency is greater than $2,5 \mathrm{~Hz}$. Vertical fundamental natural frequency is lower than limit value of $5 \mathrm{~Hz}$, therefore further vibration analysis should be done.

For further analysis it is necessary to determine the load models which will be used in assessment of maximal bridge acceleration in vertical direction. The bridge is situated at the position outside the main pedestrian routes where dense pedestrian traffic is not expected hence the load models DLM1 and DLM2 in vertical directions are taken into further analysis. The damping ratio $\zeta$ for concrete bridge is accepted as 1,3\% (Tab. 4).

\subsection{Evaluation of accelerations due to stationary pulsating force}

Below, the evaluation of maximum vertical acceleration due to load models based on stationary pulsating force proposed in clause 4.3 will be conducted by Grundman simplified method presented in Chapter 4.4 and by software DARK developed at the Faculty of Civil Engineering, University of Rijeka. The software provides the values of natural frequencies, the period of vibration and eigenvectors, numerical and graphical representation of the mode shapes, and numerical and graphical presentation of deflection, velocity or acceleration of any node in time.

Maximum acceleration by Grundman, due to a single pedestrian (DLM1), according to Eq. (20) is

$a_{p, v}=\frac{180}{3,684 \times 10^{4}} \cdot \frac{\pi}{0,082}\left(1-\mathrm{e}^{-25,56 \cdot 0,082}\right)=0,164 \mathrm{~m} / \mathrm{s}^{2}$,

where $M_{\text {gen }}=0,385 \cdot \mathrm{m} \cdot \mathrm{l}$ for one span beam fixed at both ends [32], $n=l / l_{s}$, and step length is $l_{s}=0,9 \mathrm{~m}$.
Maximum acceleration due to the group of pedestrians (DLM2) by Grundman is estimated in two ways: (a) without and (b) with additional mass of $800 \mathrm{~kg}$. In the case (a) the maximum acceleration is evaluated as the acceleration due to single pedestrian times the factor of synchronization $k_{v}\left(f_{v}\right)$.

$a_{g p, v}=a_{p, v} \cdot k_{v} \cdot 2,79=0,165 \cdot 1,84=0,302 \mathrm{~m} / \mathrm{s}^{2}$

In the case (b) the additional mass of $800 \mathrm{~kg}$ is taken into account. The fundamental natural frequency with added mass, calculated according to Eq. (17), is $f_{v}=2,78$ Hz. The Eq. (20) is modified for taking into account the factor of synchronization and added mass:

$a_{g p, v}=\frac{F \cdot k_{v}\left(f_{v}\right)}{M_{\text {gen }}+m} \cdot \frac{\pi}{\delta}\left(1-\mathrm{e}^{-n \cdot \delta}\right), \mathrm{m} / \mathrm{s}^{2}$.

According to Eq. (23) and $M_{\mathrm{gen}}+m=37640 \mathrm{~kg}$, $k_{v}(2,78)=1,88$ the value of $a_{g p, v}$ is $0,302 \mathrm{~m} / \mathrm{s}^{2}$ which is the same value as in case without added mass.

The vertical acceleration due to single pedestrian and group of pedestrians will also be calculated using the software DARK [35] which is suitable for dynamic analysis of $2 \mathrm{D}$ structures due to moving or stationary forces $[36 \div 38]$.

The bridge is modelled by using 50 beam elements of $0,46 \mathrm{~m}$ length. The model has 51 nodes. To conduct dynamic analysis it is necessary to define the time step $\Delta t$, the number of time steps $n$, the pulsating force amplitude $A$, the position of the pulsating force (node), beginning time $t_{b}$ and end time $t_{e}$ of force acting and the damping ratio $\zeta$. The structural mass (mass of the permanent load) associated with each node is generated by software. Also, it is possible to add mass at any node in the model.

Calculated fundamental natural frequency of bridge is the same as the one determined by Eq. (17), i.e. $f_{v}=$ $2,79 \mathrm{~Hz}$.

Maximum acceleration in the middle of the span due to DLM1 is calculated by using the following data: $\Delta t=$ 0,00916 seconds, $n=1000, t_{b}=0$ seconds, $t_{e}=l / v=$ $l /(0,9 \cdot f v)=9,16$ seconds, $\zeta=1,3 \%, A=180 \mathrm{~N}$. The pulsating force acts at the most adverse position, at the node 26 in the middle of the span.

In Fig. 9, it can be seen that maximum acceleration due to DLM1 is $a_{p, v}=0,158 \mathrm{~m} / \mathrm{s}^{2}$.

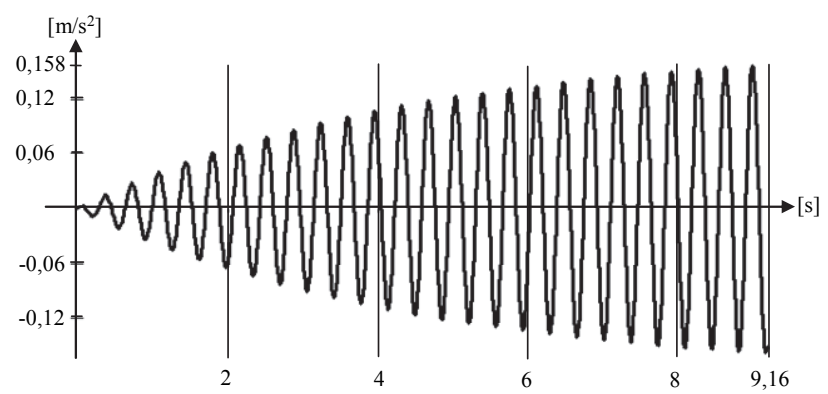

Figure 9 Acceleration in time of node 26 due to DLM1

As in the case when the simplified method by Grundmad is used, the maximum acceleration due to group of pedestrians (DLM2) is determined in two ways: (a) without and (b) with additional mass. 
In case (a) the maximum acceleration is determined as maximum acceleration due to DLM1 times factor of synchronization $k_{v}(2,79)=1,84$. Therefore $a_{g p, v}$ is 0,291 $\mathrm{m} / \mathrm{s}^{2}$.

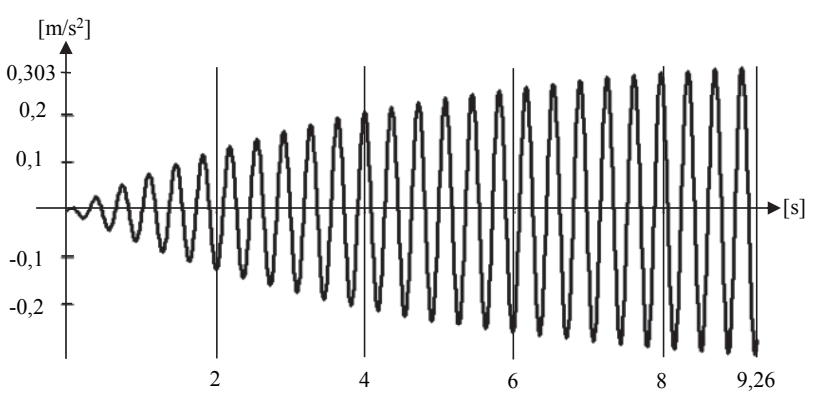

Figure 10 Acceleration in time of node 26 due to DLM2 with added mass

In case (b) the mass of $800 \mathrm{~kg}$ is added at node 26 . The fundamental natural frequency with added mass is $f_{v}$ $=2,76 \mathrm{~Hz}$. The following data are used: $\Delta t=0,00926 \mathrm{~s}, n$ $=1000, t_{b}=0 \mathrm{~s}, t_{e}=l / v=l /(0,9 \cdot f v)=9,26 \mathrm{~s}, A=$ $180 \cdot k_{v}(2,76)=180 \cdot 1,96 \cong 353 \mathrm{~N}, \zeta=1,3 \%$. The pulsating force acts at the most adverse position, at the node 26 in the middle of the span.

In Fig. 10, it can be seen that maximum acceleration due to DLM2 with added mass is $a_{p, v}=0,303 \mathrm{~m} / \mathrm{s}^{2}$. The model with added mass gives unfavourable value of maximum acceleration in comparison to the model without added mass.

Relevant maximum acceleration for serviceability verification due to group of pedestrians is the value of $0,303 \mathrm{~m} / \mathrm{s}^{2}$ calculated on the model with added mass.

\subsection{Evaluation of accelerations due to moving pulsating force}

Maximum vertical accelerations due to load models based on moving pulsating force which represent one pedestrian and group of pedestrians will be calculated using the software DARK. The numerical model is the same as in clause 5.1 as well as the calculated vertical frequency.

The load models for single pedestrian and group of pedestrians, which move with speed of $v=0,9 \cdot f_{v}$, are represented by Eq. (24) and (25), respectively.

$$
\begin{aligned}
& F_{g p, v}(t)=280 \cdot \sin \left(2 \cdot \pi \cdot f_{v} \cdot t\right), \mathrm{N} \\
& F_{g p, v}(t)=280 \cdot k_{v}\left(f_{v}\right) \cdot \sin \left(2 \cdot \pi \cdot f_{v} \cdot t\right) . \mathrm{N}
\end{aligned}
$$

To conduct dynamic analysis it is necessary to define the time step $\Delta t$, the number of time steps $n$, the pulsating force amplitude $A$, the force speed $v$, the nodes over which pulsating force is moving, total time $t$ of force acting and the damping ratio $\zeta$. Maximum acceleration in the middle of the span due to single pedestrian is calculated by using the following data: $\Delta t=0,00916$ seconds, $n=1000, v=2,51 \mathrm{~m} / \mathrm{s}, t=9,16 \mathrm{~s}, \zeta=1,3 \%, A=$ $280 \mathrm{~N}$. The pulsating force moves over all nodes ( 1 to $51)$.
In Fig. 11, it can be seen that maximum calculated acceleration due to moving pulsating force which represents single pedestrian is $a_{p, v}=0,162 \mathrm{~m} / \mathrm{s}^{2}$.

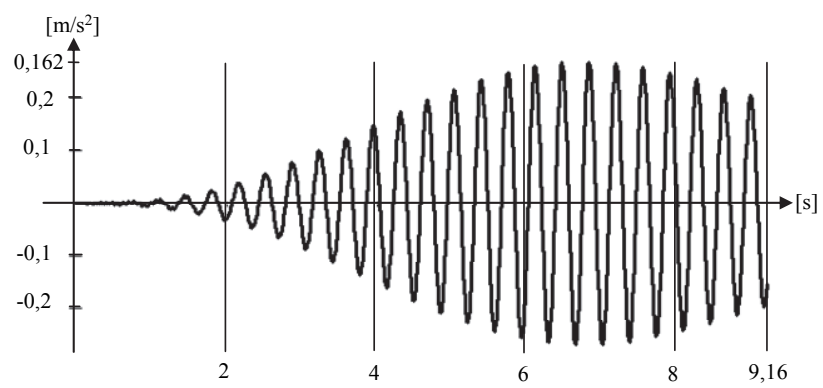

Figure 11 Acceleration in time of node 26 due to moving pulsating force (one pedestrian)

Maximum acceleration due to group of pedestrians without additional mass is determined as maximum acceleration due to moving force which represents single pedestrian times factor of synchronization $k_{v}(2,79)=1,84$. Therefore $a_{g p, v}$ is $0,298 \mathrm{~m} / \mathrm{s}^{2}$.

In case of model with additional mass of $800 \mathrm{~kg}$ at node 26 , the fundamental natural frequency is $f_{v}=2,76$ $\mathrm{Hz}$. The following data for determination of maximum acceleration are used: $\Delta t=0,00926 \mathrm{~s}, n=1000, v=2,484$ $\mathrm{m} / \mathrm{s}, t=9,26 \mathrm{~s}, \zeta=1,3 \%, A=280 \cdot k_{v}(2,76)=280 \cdot 1,96 \cong 545$ $\mathrm{N}$. The pulsating force moves over all nodes (1 to 51 ).

In Fig. 12, it can be seen that maximum calculated acceleration on model with added mass due to moving pulsating force which represents group of pedestrians is $a_{p, v}=0,311 \mathrm{~m} / \mathrm{s}^{2}$.

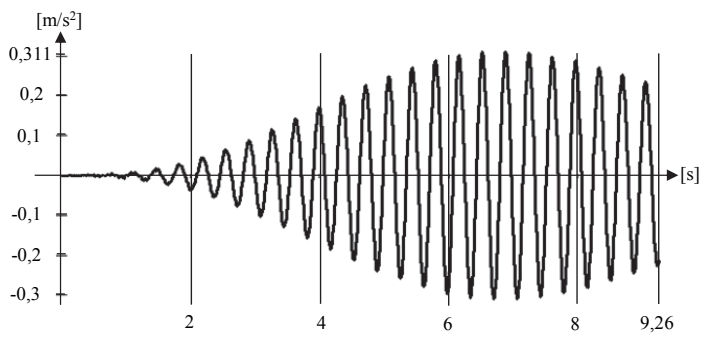

Figure 12 Acceleration in time of node 26 due to moving pulsating force (group of pedestrians)

\section{Discussion}

In Tab. 5, there are shown maximum accelerations calculated for single and group pedestrian models using simplified method by Grundman and DARK software. As it can be seen from results of conducted dynamic analyses all calculated maximum vertical accelerations are lower than limit value of $0,7 \mathrm{~m} / \mathrm{s}^{2}$, thus serviceability limit state in relation to vibration is satisfied.

Table 5 Values of maximum vertical acceleration $\left(\mathrm{m} / \mathrm{s}^{2}\right)$

\begin{tabular}{|l|c|c|c|}
\hline \multirow{2}{*}{$\begin{array}{l}\text { Pedestrian } \\
\text { load model }\end{array}$} & \multicolumn{2}{|c|}{ Stationary force } & Moving force \\
\cline { 2 - 4 } $\begin{array}{l}\text { Single } \\
\text { pedestrian }\end{array}$ & 0,164 & DARK & DARK \\
\hline $\begin{array}{l}\text { Group of } \\
\text { pedestrians }\end{array}$ & $0,302 *$ & 0,158 & 0,162 \\
\hline$*$ model without added mass & $0,291 *$ & $0,298^{*}$ \\
$* *$ model with added mass (unfavourable) & $0,311^{* *}$ \\
\hline
\end{tabular}


Comparison of maximum acceleration calculated by software DARK for moving pulsating forces and stationary pulsating forces shows difference of 2,5\% for single pedestrian load models, $2,5 \%$ for model of group of pedestrians without added mass and 2,6\% for model of group of pedestrians with added mass. These comparisons show that proposed stationary pulsating load models and moving pulsating load models give similar dynamic response of the structure.

Maximum accelerations due to stationary pulsating force calculated using simplified method by Grundman are greater by 3,8 \% than acceleration calculated using software solution for single pedestrian load model and group of pedestrians load model without added mass. In case of group of pedestrians load model with added mass the difference is under $1 \%$.

\section{Conclusion}

In this paper, the extensive state of art in the field of pedestrian load models and vibration comfort criteria for pedestrian bridges is presented. Using the collected data a design procedure for verification of the serviceability limit state of pedestrian bridges related to vibration due to pedestrians is proposed. The procedure, also, includes determination of the pedestrian load models for serviceability verification which is missing in the current European codes, as well as in the Croatian National Annex to European codes for traffic loads on bridges. For the reason of simplicity of serviceability verification pedestrian load models proposed in this paper are based on stationary pulsating loads instead of moving pulsating loads which can be found in previous versions of European codes.

Verification of the serviceability limit state related to vibration due to pedestrians is conducted on a model of pedestrian bridge in the Maksimir Park in Zagreb. Conducted analysis shows that proposed stationary pulsating load models can be used as efficient substitution for moving pulsating load models in vibration serviceability verification. Also, it can be seen that both, simplified procedure and software solution, can be equally used in verification of the serviceability limit state related to vibration due to pedestrians.

\section{Acknowledgment}

The author thanks the University of Rijeka for supporting the publication of this paper through grant No. 13.05.1.1.01.

\section{References}

[1] Cunha, A.; Moutinho, C. Active Control of Vibrations in Pedestrian Bridges. 1999. URL: http://repositorioaberto.up.pt/handle/10216/463?mode=full. (03.05.2013.)

[2] Živanović, S.; Pavic, A.; Reynolds, P. Vibration serviceability of footbridges under human-induced excitation: a literature review. // Journal of Sound and Vibration. 279 (2005), pp. 1-74. DOl: 10.1016/j.jsv.2004.01.019

[3] FIB Bulletin 32: Guidelines for the design of footbridges. CEB, Stuttgart, 2005.
[4] Heinemeyer, C. et al. Design of Lightweight Footbridges for Human Induced Vibrations. European Commission, Institute for the Protection and Security of the Citizen, Italy, 2009.

[5] Bachnamm, H. et al. Vibration problems in structures: practical guidelines. Birkhauser Verlag Basel, Basel, 1995.

[6] Živanović, S.; Díaz, I. M.; Pavić, A. Influence of Walking and Standing Crowds on Structural Dynamic Properties. // Proceedings of the IMAC-XXVII / Orlando, 2009, pp. 110.

[7] Gimsing, N. J.; Georgakis, C. T. Cable Supported Bridges: Concept and Design. 3rd ed. John Wiley and Sons, West Sussex, 2012.

[8] Ingólfsson, E. T.; Georgakis, C. T.; Jönsson, J. Pedestrianinduced lateral vibrations of footbridges: A literature review. // Engineering Structures. 45 (2012), pp. 21-52. DOI: 10.1016/j.engstruct.2012.05.038

[9] Hauksson, F. Dynamic Behaviour of Footbridges Subjected to Pedestrian-Induced Vibrations. Master's Dissertation, Division of Structural Mechanics, LTH, Lund University, Lund, Sweden, 2005.

[10] Stráský, J. Stress Ribbon and Cable-Supported Pedestrian Bridges. Thomas Telford, London, 2005. DOl: 10.1680/sracspb.32828

[11] Blanco, C. M. et al. Structural Dynamic design of a footbridge under pedestrian loading. // Proceeding of $9^{\text {th }}$ SAMTECH Users Conference / Paris, 2005, pp. 1-19.

[12] Guidelines for the vibration serviceability limit state of pedestrian bridges // Structural Assessment / Pimentel, R. L.; Waldron, P. E and FN Spon, London, 1997. pp. 399346.

[13] Footbridges: Assessment of vibrational behaviour of footbridges under pedestrian loading. SETRA, Association Francaise de Dgenie Civil, 2006.

[14] da Silva, J. G. S. et al. Vibration analysis of footbridges due to vertical human loads. // Computer and structures. 85(2007), pp. 1693-1703. DOI: 10.1016/j.compstruc.2007.02.012

[15] Bachman, H.; Amman, W. Vibration in Structures Induced by Man and Machines. IABSE, Honggerberg, 1987.

[16] Steel, Concrete and Composite Bridges-Part 2: Specification for Loads; Appendix C: Vibration Serviceability Requirements for Foot and Cycle Track Bridges, BS 5400. UK: British Standards Association, London, 1978.

[17] Design Manual for Road and Bridges: Loads for Highway Bridges: BD 37/01. Highway Agency, London, February, 2002.

[18] HRN ENV 1992-2:1996, Eurokod 2: Projektiranje betonskih konstrukcija - 2. dio: Betonski mostovi. Državni zavod za normizaciju i mjeriteljstvo, Zagreb, 2004.

[19] ENV 1995-2: 1997, Eurocode 5: Design of Timber Structures-Part 2: Bridges. European Committee for Standardization, Brussels, 1997.

[20] HRN EN 1991-2:2012, Eurokod 1: Djelovanja na konstrukcije - 2. dio: Prometna opterećenja mostova, Hrvatski zavod za norme, Zagreb, 2012.

[21] HRN EN 1991-2:2012/NA:2012, Eurokod 1: Djelovanja na konstrukcije - 2. dio: Prometna opterećenja mostova nacionalni dodatak, Hrvatski zavod za norme, Zagreb, 2012.

[22] Guide to basis of bridge design related to Eurocodes supplemented by practical design - Handbook 4. Edited by Luca Sanpaolesi and Pietro Croce, Leonardo da Vinci pilot project, Pisa, 2004.

[23] Aničić, D. Ispitivanje konstrukcija. Građevinski fakultet Osijek, 2002.

[24] SIA Standard 260: Action on structures. Swiss Society of Engineers and Architects, Zurich, 2004. 
[25] CEB-FIB Model Code 1990 (MC-90), Design Code. Comité Euro-International du Béton (CEB), Thomas Telford Services Ltd., London, 1993.

[26] Model Code 2010, First complete draft, Volume 2. Document Competence Center Siegmar Kästl e.K., 2010.

[27] HRN EN 1990:2011, Eurokod: osnove projektiranja konstrukcija. Hrvatski zavod za norme, Zagreb, 2011.

[28] Guide Specifications for Design of FRP Pedestrian Bridges. American Association of State Highway and Transportation Officials (AASHTO), 2008.

[29] Modifications for AASHTO LRFD Bridge Design Specifications to Incorporate or Update the Guide Specifications for Design of Pedestrian Bridges. American Association of State Highway and Transportation Officials (AASHTO), 2009.

[30] Design of footbridges - Guideline - Human induced Vibration of Steel Structures, URL: http://repositorioaberto.up.pt/bitstream/10216/67114/2/952261.pdf. (17.07.2013.)

[31] Tomičić, I. Betonske konstrukcije. Društvo hrvatskih građevinskih konstruktora, Zagreb, 1996.

[32] Hurti, W. C, Rubinštajn, M. F; Dinamika konstrukcija, Beogradski izdavačko-grafički zavod, Beograd, 1973.

[33] HRN EN 1995-2:2013, Eurokod 5: Projektiranje drvenih konstrukcija - 2. dio: Mostovi . Hrvatski zavod za norme, Zagreb, 2012.

[34] Građevinski projekt - Idejni projekt konstrukcije. Pješački most 1 na k.č. k.č.br. 4927, 4928, 4929 k.o. Maksimir, Zagreb. Glavni projektatnt: H. Nijrić, Projektant konatrukcije: I. Palijan, Zagreb, 2010.

[35] Kožar, I. Program DARK. Građevinski fakultet Sveučilišta u Rijeci, 2010.

[36] Štimac, I.; Meštrović, D.; Kožar, I. Analiza mostovnih konstrukcija pobuđenih pokretnim opterećenjem. // Građevinar. 56, 6(2004), pp. 347-353.

[37] Štimac Grandić, I. Grandić, D. Mužić, R. Određivanje dinamičkog koeficijenta na mostovima. // e-gfos. 6, (2013), pp. 23-33.

[38] Drobac, J. Proračun graničnog stanja vibracija na pješačkim mostovima. Diplomski rad, Rijeka, 2011.

\section{Author's addresses}

Doc. dr. sc. Ivana Štimac Grandić, dipl. ing. građt. Faculty of Civil Engineering, University of Rijeka Radmile Matejčić 3, 51000 Rijeka, Croatia Phone: +385 51265952

E-mail: ivana.stimac@gradri.hr 